\title{
MISSISSIPPIAN EFFIGY PIPES AND THE GLENDON LIMESTONE
}

\author{
Vincas P. Steponaitis and David T. Dockery III
}

\begin{abstract}
Large effigy pipes made of limestone are found at Mississippian sites across much of the American South. Here we examine a sample of these pipes with the goal of identifying their geological sources, which are inferred from the fossils visible in the rock. All but one of the pipes in our sample are made of Glendon limestone, a distinctive material that outcrops most abundantly near Vicksburg, Mississippi. Based on the geological and distributional evidence, we argue that these Glendon limestone pipes were crafted in the Lower Mississippi Valley. Our study also demonstrates the efficacy of using fossils as a nondestructive way of determining the provenance of limestone artifacts.
\end{abstract}

Largos tubos efigies de roca caliza se encuentran en sitios misisipienses a lo largo de una gran parte del sur de los Estados Unidos. En el presente se examina una muestra de estos tubos con el objetivo de identificar sus fuentes geológicas, las cuales se pueden inferir en base a los fósiles visibles en las rocas. Todos los tubos en la muestra, a excepción de uno, son representativos de la Caliza Glendon, un material distintivo que aflora con gran abundancia cerca de Vicksburg, Misisipi. Basado en la evidencia geológica y distribucional, se argumenta que tales tubos de Caliza Glendon fueron tallados en la llanura del Curso Inferior del Misisipi. Este estudio también demuestra la eficacia de la utilización de fósiles como un método no destructivo para determinar la proveniencia de artefactos de rocas calcáreas.

I

$t$ is well known that the Mississippi period in the American South (A.D. 1000-1700) was a time of artistic florescence, during which figural art-images of supernatural animals and humans-were crafted in a variety of media, including stone, pottery, shell, and copper (Knight et al. 2001). Contrary to earlier views that all of this art belonged to a single "Southeastern Ceremonial Complex," we now know that it was produced in a number of distinctive regional styles and was used and understood in regionally distinctive ways (Brain and Phillips 1996:398; Brown 1989, 2004; Knight 2006). Yet recognizing these regional styles is sometimes made difficult by the fact that objects were often moved to places far from where they were made. Thus, the assemblage of imagery found at any given Mississippian center is likely to include a mixture of local products and imports, thereby blurring our perception of what constitutes the local style, as well as the nature of long-distance social interac-

tions (Knight and Steponaitis 2011; Steponaitis and Knight 2004).

Sorting out such mixtures often requires provenance studies, which link the raw materials in these objects to particular geological sources. Geological provenance, especially when combined with geographical data and stylistic comparisons, can provide powerful evidence for where Mississippian objects were actually made and thereby can give us a clearer view of the patterns of craft production and distribution in ancient times.

Our goal in this essay is to determine the provenance of one distinctive category of Mississippian figural art: large limestone effigy pipes that are found over a wide area including Arkansas, Louisiana, Mississippi, and Alabama. We do so using a novel but rather simple technique: the geological source of the stone is inferred from the fossils visible in its surface. In contrast to the techniques that have been usefully employed in provenance studies of other materials, our method

Vincas P. Steponaitis — Research Laboratories of Archaeology, University of North Carolina at Chapel Hill, CB\# 3120 Chapel Hill, NC 27599-3120 (vin@unc.edu)

David T. Dockery III - Mississippi Office of Geology, PO Box 2279, Jackson, MS 39225 (David_Dockery@deq.state.ms.us)

American Antiquity 76(2), 2011, pp. 345-354

Copyright (C2011 by the Society for American Archaeology 
is completely nondestructive and requires no instruments other than a hand lens. It works because the stone used in making the pipes is highly fossiliferous and the limestone deposits available in the South vary greatly in geological age, thereby yielding different and distinctive fossil assemblages.

We begin by describing the sample of effigy pipes that were examined, focusing on their general characteristics and geographical distribution. Next we present the evidence that links these pipes to the Glendon limestone, which outcrops most prominently near Vicksburg, Mississippi. And finally we discuss the implications of this result for understanding regional art styles and the movement of elaborately crafted objects across the Mississippian world.

\section{The Sample}

Our sample consists of 18 limestone effigy pipes that were found at seven different Mississippian sites (Table 1, Figure 1). These generally fall into two groups. The first comprises a dozen pipes that Brain and Phillips assigned to their "Bellaire style." These pipes all depict supernatural beings in the round that show, in varying combinations, the characteristics of panthers, snakes, and raptors. These creatures, when depicted in their entirety, are typically placed in a crouching position with the pipe's bowl on the top and the stem hole in the rear, so that the being faces away from the smoker.

Iconographically, the versions that mainly show panther or snake characteristics are surely depictions of the Underwater Panther or Great Serpent, two aspects of the same supernatural being who was well known to native peoples across the Great Plains and Eastern Woodlands (Lankford 2007a). The raptors may well be creatures associated with equally widespread stories about the path that souls take after death (Aftandilian 2007:438-449; Lankford 2007b). Although a full analysis of style is far beyond the scope of this essay, we agree with Brain and Phillips that these pipes show some stylistic coherence, even if not perfectly so. Yet the common denominator of these pipes lies not only in style (execution) but also in theme (subject matter) and medium (stone). If and when a true Bellaire style is defined, it will probably contain a broader range of themes and media, perhaps analogous to what Brain and Phillips have called the "Bellaire style system" (1996:390-396; cf. Knight and Steponaitis 2011). Thus, for present purposes, we use a more neutral term and simply call them the Bellaire group.

The Bellaire pipes were initially the main focus of our study. But in the process of examining these objects at various museums, we also had the opportunity to look at a number of other limestone pipes from the same or closely related sites. These six effigies constitute our "other pipes," essentially a catchall category for pipes that differ thematically from the Bellaire group. Two depict crouching humans and come from sites in the Lower Mississippi Valley; Brain and Phillips note that one of these "is related to the Bellaire style of animal effigy pipes" (1996:384). Suffice it to say for now that we agree that this relationship exists and may well be the basis for ultimately placing these pipes in the same, overarching style. The four remaining pipes were all found at the Moundville site in Alabama and represent four different themes: a man holding a pipe (whose bowl is shaped like a pot), a pot by itself, a raptor, and a likely frog (but too eroded for us to be certain).

Our sample includes most, but not all, of the limestone pipes that Brain and Phillips assigned to their "Bellaire style." Of the 19 pipes they compiled, 12 are in our sample. Most of the missing pipes are viewed by Brain and Phillips as unusual or "degenerate" examples of the style, although one (ArkCh-AP1) is the classic example from the Bellaire site in Arkansas believed to have been made by the same hand as one of the pipes (Ala-Tu-M1) we examined from Moundville in Alabama (for illustrations, see Jeter 2007:Figure 9.2; Lemley and Dickinson 1937:Plates 5-6, 1964:Figure 2; Penney 1985:Plate 130). Regrettably, we did not have the opportunity to look at any of the pipes from Spiro in Oklahoma.

All but one of the pipes in Table 1 were examined by both of us in person, macroscopically and with a hand lens. One of us (Steponaitis) had the archaeological expertise to select the appropriate pipes, and the other (Dockery) provided the paleontological expertise to identify the visible fossils. One pipe (Ala-Tu-M161) was examined in person only by the former, but his identification of the key fossils was confirmed by the latter from photographs. 


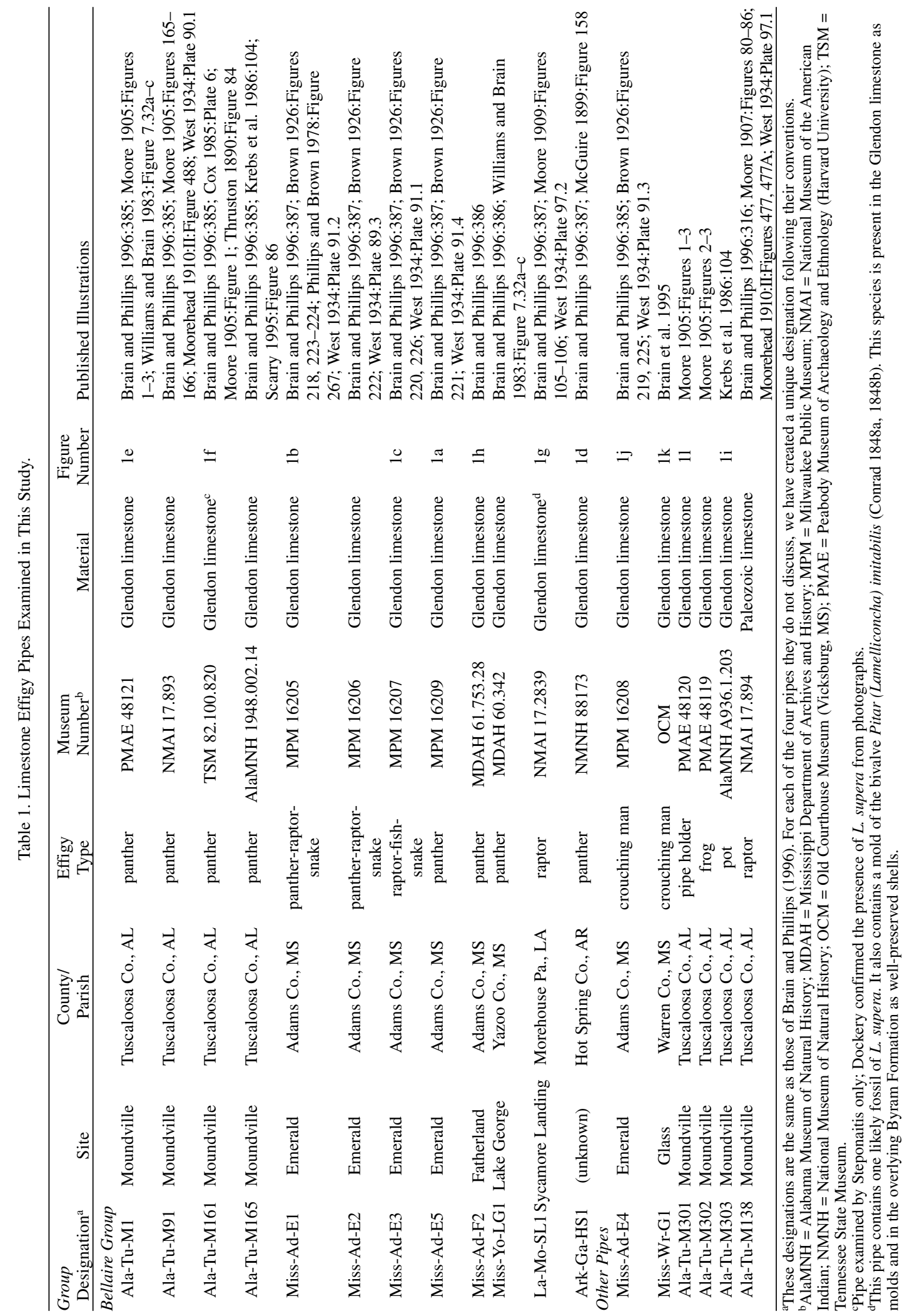




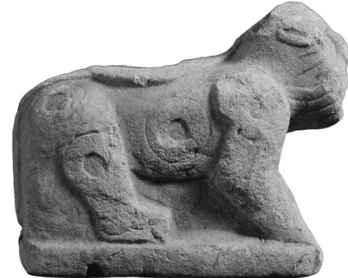

a

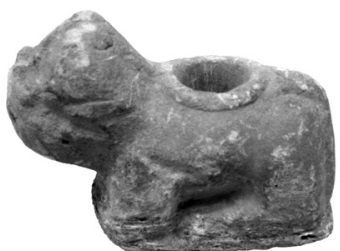

d

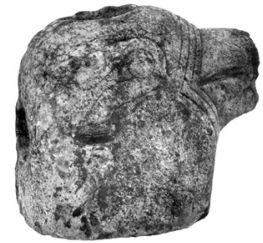

g

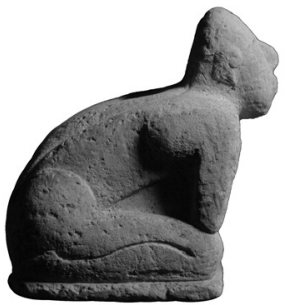

j

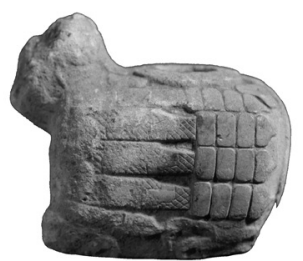

b

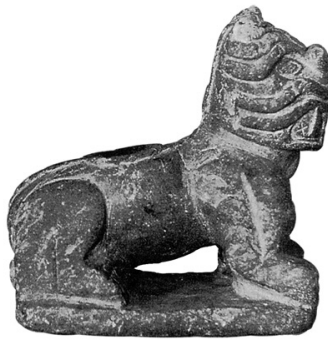

e

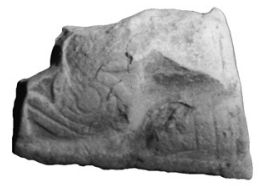

h

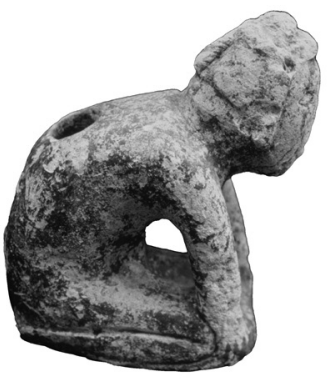

k

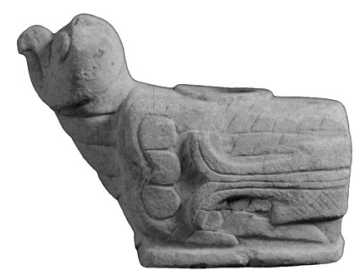

c

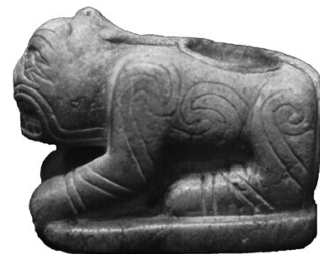

f

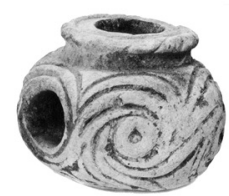

i

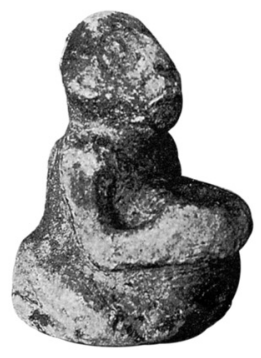

I

Figure 1. Selected limestone effigy pipes: (a-h) Bellaire group; (i-l) other pipes. See Table 1 for site and catalog information.

\section{Geological Provenance}

Seventeen of the 18 pipes in our sample are made of exactly the same material-a cream-colored, fossiliferous limestone. Many kinds of fossils are visible in the surface, including pectens, gastropods, and Foraminifera. Of all the visible species, one is particularly important in linking the rock to a single geological deposit. This fossil is a
Foraminifera called Lepidocyclina supera, and the geological deposit of which it is characteristic is called the Glendon limestone.

L. supera is a large species of Foraminifera, which are one-celled, amoeba-like creatures with calcareous shells (or "tests") that live in marine environments. Most Foraminifera are microscopically small, with large varieties such as Lepidocyclina being the exception. Larger Foraminifera are 

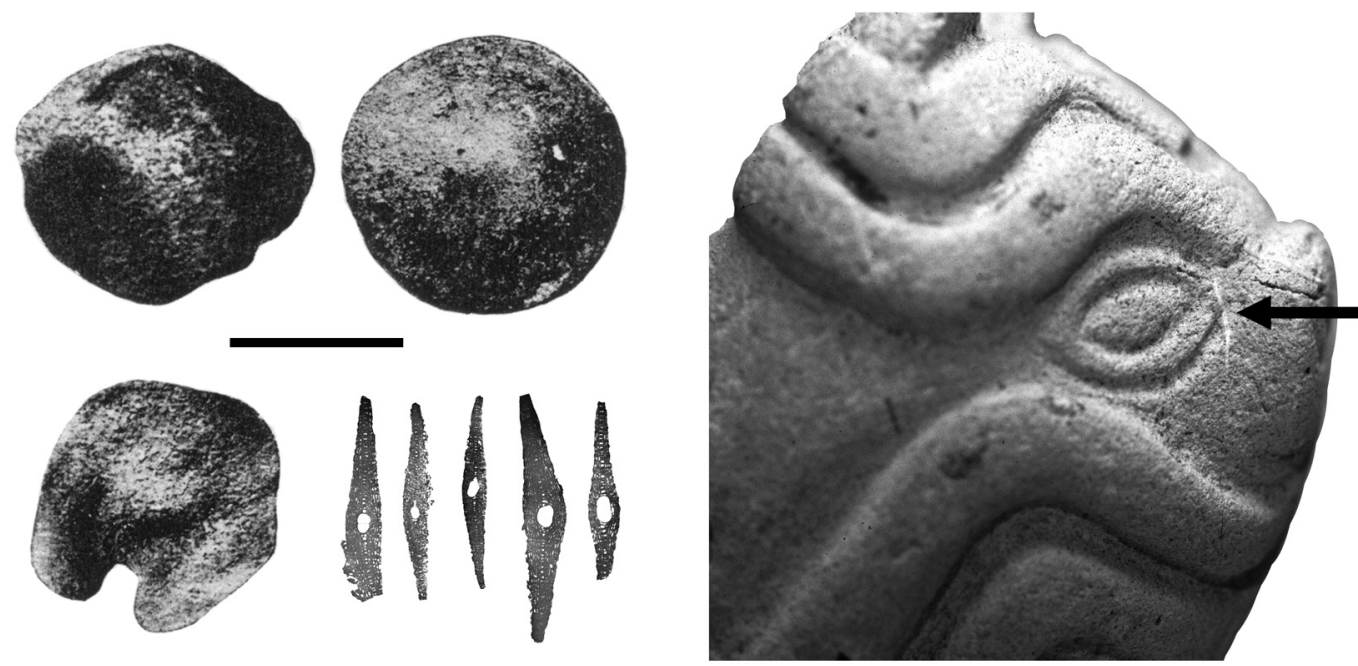

Figure 2. Lepidocyclina supera fossils: (left) orthogonal views and cross sections-scale bar equals approximately $1 \mathrm{~cm}$ (after Cushman 1920:Plate 26; Ellis and Messina 1965); (right) cross section of $L$. supera fossil, indicated by an arrow, visible in the surface of pipe Ala-Tu-M91.

readily visible as fossils in ancient rocks. $L$. supera fossils tend to be thin, wafer-like, circular disks up to $10-18 \mathrm{~mm}$ in diameter (Figure 2).

They are usually seen in cross section, where they exhibit a thin lenticular profile, thickened in the center and often slightly bent. The cross section also invariably reveals a chambered internal structure that is highly distinctive (Cushman 1920; Ellis and Messina 1965).

The Glendon limestone, the geological formation for which $L$. supera is a guide fossil, is a marine deposit of early Oligocene age (Adams et al. 1926:285-287; Dockery 1980:57-61). On geological maps, it is generally considered part of the Vicksburg Group, which runs in a long, narrow arc southeast from Vicksburg, Mississippi, across southern Alabama, dipping into the Florida panhandle and then turning northeast into Georgia (Bicker 1969; Brooks 1982; Lawton et al. 1976; Szabo et al. 1988). Theoretically, the kind of limestone used in making the pipes might occur anywhere along this arc. But in reality, the range of likely sources is much more limited, because Glendon outcrops become less prominent as one moves along the arc from west to east. The largest and most accessible deposits of "pipe-grade" material are found in extensive outcrops that stretch for more than $30 \mathrm{~km}$ in the vicinity of Vicksburg, at the base of the towering loess bluffs that define the eastern edge of the Mississippi Valley (Figure 3). Here, the massive white outcrops are a prominent feature of the landscape, and more than 90 percent of the exposed limestone is Glendon. As one moves eastward, the Glendon deposits tend to become thinner and narrower, and the underlying Marianna limestone becomes much more prominent. For example, at St. Stephens on the Tombigbee River in Alabama, only about 13 percent of the exposed limestone section consists of Glendon, while 87 percent consists of Marianna. Moreover, the Glendon deposits from central Mississippi to southern Alabama take on a much more crystalline character, recognizably different from the softer material used to make the pipes we examined. Even farther east, beyond the Conecuh River, the Glendon limestone has been "completely altered" to form a cherty residual clay (Adams et al. 1926:286).

Thus, if one were to assign a probable source based on the abundance and availability of Glendon exposures, the most likely place is the region around Vicksburg. At this location, the large and obvious outcrops of Glendon limestone are exposed in the bluffs at and just above the level of the Mississippi's floodplain (Figure 4). Where the Mississippi River touches the bluffs, the massive limestone deposits appear at the waterline. The Glendon limestone also commonly outcrops in the ravines along the bluff edge, where the ledge of 


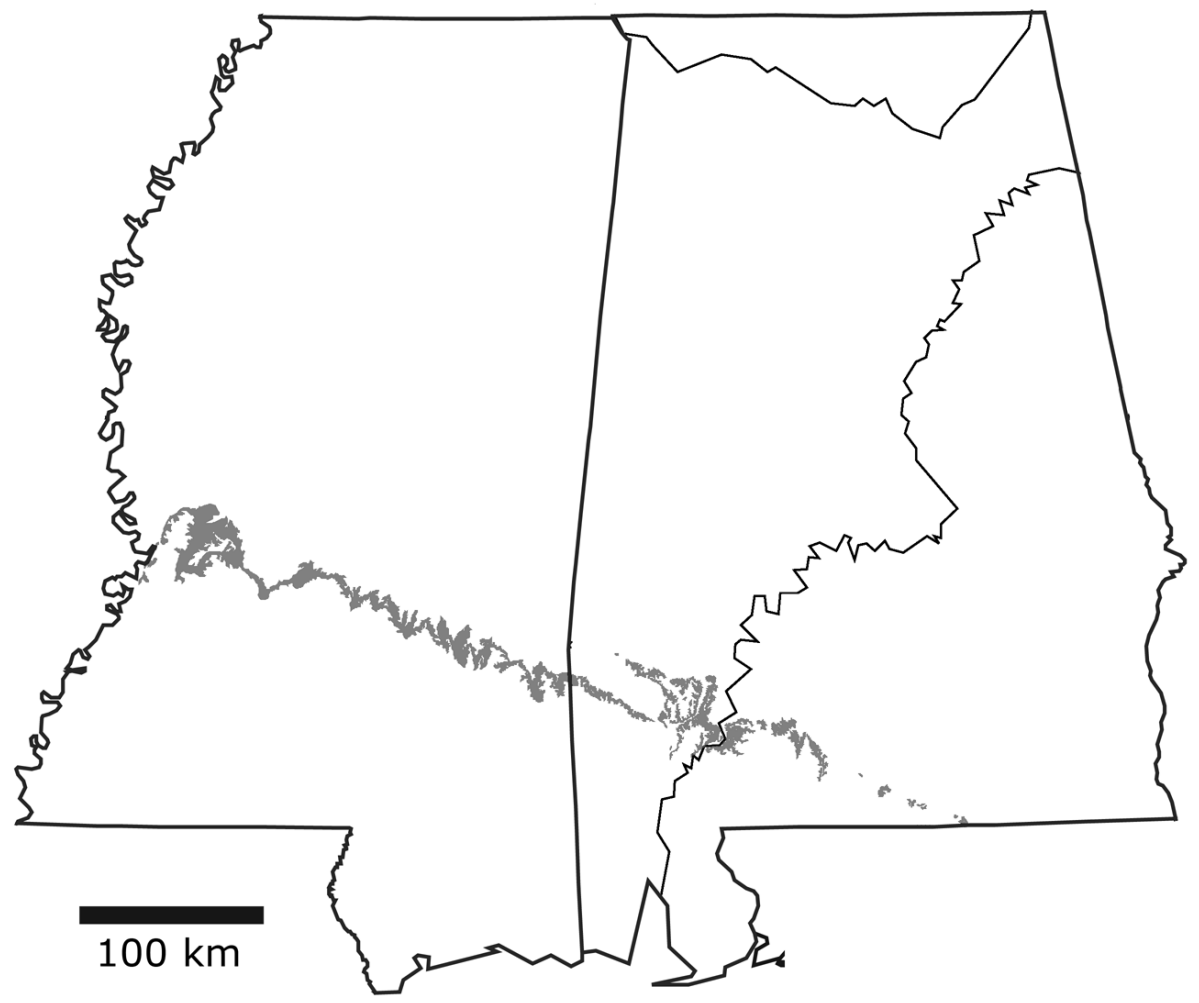

Figure 3. Oligocene limestones in Mississippi and Alabama, shown in gray (after Bicker 1969; Dicken et al. 2007; Szabo et al. 1988). The Glendon limestone makes up a subset of these deposits, most prevalent at the western end of this distribution where the deposits are exposed at the edge of the Mississippi Valley.
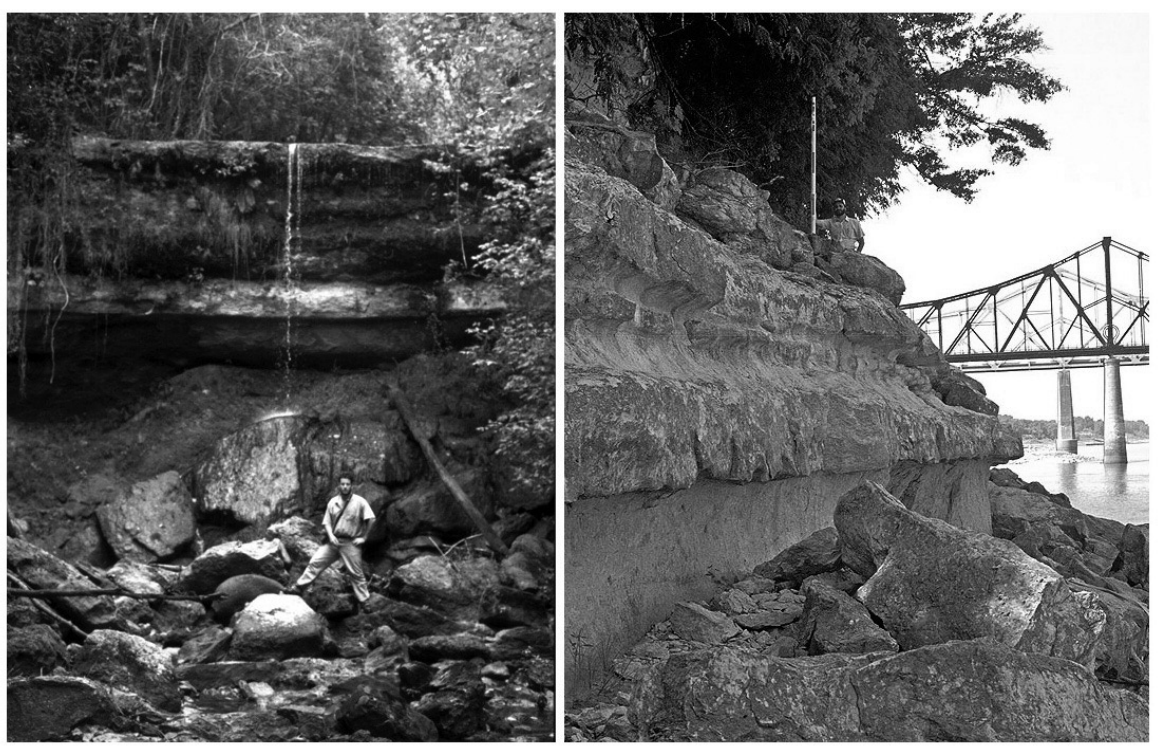

Figure 4. Outcrops of Glendon limestone near Vicksburg, Mississippi: (left) in a ravine at Mint Spring, Vicksburg National Military Park; (right) on the bank of the Mississippi River, upstream from the I-20 bridge. 


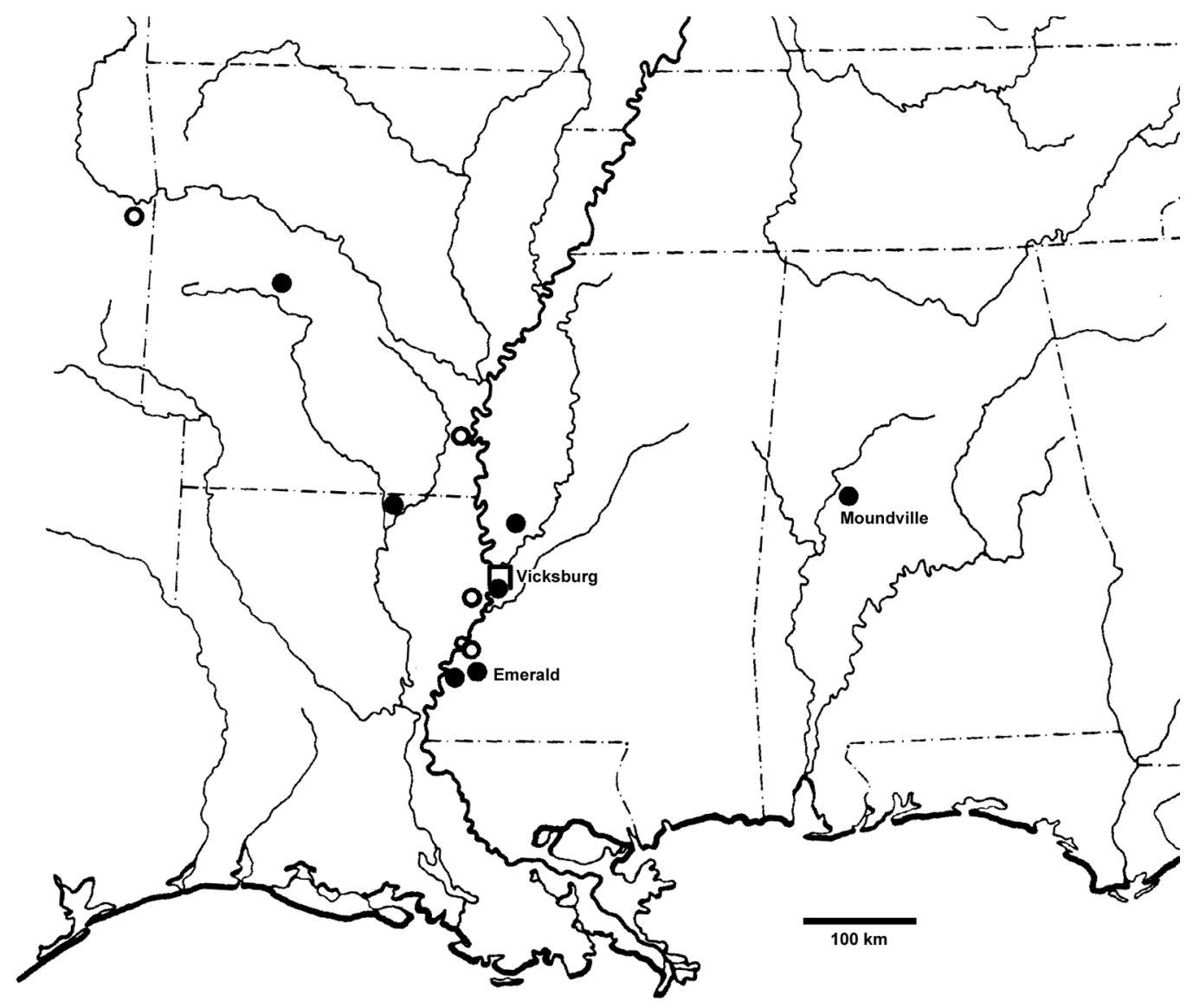

Figure 5. Geographical distribution of limestone effigy pipes assigned to the Bellaire group (after Brain and Phillips 1996:388). Solid circles = Bellaire pipes made of Glendon limestone (Table 1); open circles = Bellaire pipes not examined in this study; open square $=$ Glendon limestone outcrops near Vicksburg.

limestone typically creates waterfalls. ${ }^{1}$ Nowhere else are outcrops of this particular limestone so plentiful and easy to find. Macroscopically, the material in our pipes looks very much like the stone in these outcrops.

Two additional, independent lines of evidence can be brought to bear in support of this conclusion. Figure 5 shows the geographical spread of Bellaire pipes across the South. Note that Vicksburg is close to the center of this distribution, which is exactly what we would expect if the pipes originated there. Yet another line of evidence is stylistic. Three of the pipes made of Glendon limestone are decorated with incised scrolls like those found on the pottery types Leland Incised and Fatherland Incised, which are contemporary with these pipes in the Lower Mississippi Valley (see Figure 1f, $\mathrm{h}-\mathrm{i}$ ). The treatments at the center of the scrolls are espe- cially distinctive: circles in two cases and a continuous-line meander in the third, both of which are common in Leland and Fatherland types (Hally 1972:718-760; Neitzel 1965:Figures 19-20; Phillips 1970:104-107; Williams and Brain 1983:Figures 5.83-5.84) but rarely occur in the scrolls found on contemporary Moundville pottery (Steponaitis 1983:Figures 45, 51-53, 62-63). Thus, the links to ceramic designs also point to the Lower Mississippi Valley as the most likely manufacturing locale for these Glendon limestone pipes, which include all the examples in our Bellaire group and five of the six other pipes we examined.

It remains for us to consider the one pipe in our sample that was not made of Glendon limestone: an unusual inverted-raptor effigy from Moundville, with the head wrapped around the side of the bird and the talons shown on top (Ala-Tu-M138). The 
limestone in this pipe contained a much higher density of fossils than the Glendon examples and exhibited an entirely different suite of organisms, mostly crinoid fragments, probably early Carboniferous (Mississippian) in age. Clearly, this limestone was not quarried in the coastal plain but, rather, comes from the hard-rock areas above the fall line. Although additional study of the fauna would be required to arrive at firmer conclusions, deposits in northwest Alabama such as the Tuscumbia limestone or Bangor limestone are possible sources (Szabo et al. 1988), especially given that they had large Mississippian populations living in their vicinity and also were important sources of chert used by Moundville's inhabitants.

\section{Discussion}

The geological, distributional, and stylistic evidence indicates that all of the Bellaire pipes, as well as most of the other limestone pipes we examined, were manufactured in the Lower Mississippi Valley, probably somewhere in the region of Vicksburg. This conclusion has several interesting implications.

First and foremost, it resolves the uncertainty about where the Bellaire pipes were made. In the absence of information on geological provenance, researchers tend to assume that the place where the most objects of a particular type are found is also the place of manufacture. Most of the Bellaire pipes were found at only two sites, Emerald and Moundville, with equal numbers at both (Table 1). Moreover, all four of the Bellaire pipes at Moundville are the so-called cat pipes, which emphasize the feline characteristics of the depicted creature, and no other site has produced more than a single example of this particular form. Thus, it has long been assumed that Moundville was "home" to these pipes. This assumption has now been put to rest.

If one accepts this interpretation, yet another interesting question immediately presents itself: Why were so many pipes of this type found at Moundville, located at the far eastern edge of the type's distribution and some $300 \mathrm{~km}$ from the Lower Mississippi Valley? Surely, this does not fit the expectations of the usual "distance-decay" model of decreasing frequency with increasing dis- tance from the source. The answer, we believe, lies in two factors. One is simply the tremendous volume of excavation at Moundville, which would cause even rare artifacts to be found in much greater frequency than at sites where less dirt has been moved. But this alone does not explain the thematic consistency we see in the Moundville pipes. In other words, why so many "cats" relative to the other forms one sees in the Bellaire group? Here we may be seeing the outcome of deliberate selection. Effigy pipes were spiritually powerful objects with specific ritual uses and associations. We suspect that the ritual practitioners at Moundville sought out the pipes with powers that were important in their local religious sphere. The Underwater Panther depicted in these pipes was widely associated with the Beneath World in the native cosmos (Lankford 2007a), which fits perfectly with the emphasis on the Beneath World seen in the local art at Moundville (Knight and Steponaitis 2011; Steponaitis and Knight 2004).

Finally, our study has demonstrated the efficacy of using macrofossils to establish the geological provenance of limestone artifacts in the ancient American South. This simple technique has the advantages of being quick, inexpensive, and nondestructive, and it can be applied much more widely than it has been to date.

Acknowledgments. The following individuals facilitated our study of these pipes in the various museums we visited: Patricia Capone, Gordon Cotton, Steven Cox, Thomas Evans, Viva Fisher, Eugene Futato, Patricia Galloway, Gloria Greis, Susan Haskell, Jim Hoobler, James Krakker, Mary Jane Lenz, Diana Loren, Ann McMullen, Jo Miles-Seeley, Mick Morin, Patricia Nietfeld, and Jeff Sellers. Stephen Williams provided crucial support for our travel to these museums, as did the Graham Research Fund at the University of North Carolina at Chapel Hill. Bill Nichols and Greg Zeman gave permission to collect Glendon limestone samples in Vicksburg National Military Park. Ian Brown, Chris Wilkins, and Hobbs Freeman helped collect these samples. Dave Aftandilian, Ian Brown, Jeffrey Brain, Marvin Jeter, Tristram R. Kidder, Jim Knight, George Lankford, Laurie Steponaitis, and an anonymous reviewer provided comments on an earlier draft. David Mora-Marín graciously translated the abstract into Spanish. We are grateful to all for their assistance. A very early version of this essay was presented at the Annual Meeting of the Southeastern Archaeological Conference in 1997. The writing was supported by a Reynolds Fellowship and a Research and Study Assignment provided to Steponaitis by the University of North Carolina at Chapel Hill. 


\section{References Cited}

Adams, George I., Charles Butts, L. W. Stephenson, and Wythe Cook

1926 Geology of Alabama. Special Report 14. Geological Survey of Alabama, University.

Aftandilian, Dave

2007 Animals, Agriculture, and Religion Among Native Americans in Precontact Illinois: An Interdisciplinary Analysis of Perception and Representation. Unpublished Ph.D. dissertation, Department of Anthropology, University of Chicago.

Bicker, Alvin R., Jr.

1969 Geologic Map of Mississippi. Mississippi Geological Survey, Jackson.

Brain, Jeffrey P., Ian W. Brown, and Vincas P. Steponaitis

1995 Archaeology of the Natchez Bluffs. Manuscript on file, Research Laboratories of Archaeology, University of North Carolina, Chapel Hill.

Brain, Jeffrey P., and Philip Phillips

1996 Shell Gorgets: Styles of the Late Prehistoric and Protohistoric Southeast. Peabody Museum Press, Cambridge, Massachusetts.

Brooks, Harold K.

1982 Geologic Map of Florida. Center for Environmental and Natural Resources, University of Florida, Gainesville.

Brown, Calvin S.

1926 Archaeology of Mississippi. Mississippi Geological Survey, University.

Brown, James A.

1989 On Style Divisions of the Southeastern Ceremonial Complex-A Revisionist Perspective. In The Southeastern Ceremonial Complex, Artifacts and Analysis: The Cottonlandia Conference, edited by Patricia K. Galloway, pp. 183-204. University of Nebraska Press, Lincoln.

2004 The Cahokian Expression: Creating Court and Cult. In Hero, Hawk, and Open Hand: American Indian Art of the Ancient Midwest and South, edited by Richard F. Townsend and Robert V. Sharp, pp. 104-123. Art Institute of Chicago, Chicago.

Conrad, Timothy Abott

1848a Observations on the Eocene Formation, and Descriptions of One Hundred and Five New Fossils of That Period, from the Vicinity of Vicksburg, Mississippi; with an Appendix. Journal of the Academy of Natural Sciences of Philadelphia, Second Series, 1:111-134, Plates 11-14.

1848b Observations on the Eocene Formation, and Descriptions of One Hundred and Five New Fossils of That Period, from the Vicinity of Vicksburg, Mississippi; with an Appendix. Proceedings of the Academy of Natural Sciences of Philadelphia 3:280-299.

Cox, Stephen D. (editor)

1985 Art and Artisans of Prehistoric Middle Tennessee: The Gates P. Thruston Collection of Vanderbilt University Held in Trust by the Tennessee State Museum. Tennessee State Museum, Nashville.

Cushman, Joseph A.

1920 The American Species of Orthophragmina and Lepidocyclina. U.S. Geological Survey Professional Paper 125. Government Printing Office, Washington, D.C.

Dicken, Connie L., Suzanne W. Nicholson, John D. Horton, Michael P. Foose, and Julia A. L. Mueller

2007 Preliminary Integrated Geologic Map Databases for the United States: Alabama, Florida, Georgia, Mississippi, North Carolina, and South Carolina. Open-File Report 2005-1323. Version 1.1, updated December 2007. U.S. Geological Survey, Reston, Virginia.
Dockery, David T., III

1980 The Invertebrate Macropaleontology of the Clarke County, Mississippi, Area. Bulletin 122. Mississippi Department of Natural Resources, Bureau of Geology, Jackson.

Ellis, Brooks F., and Angelina R. Messina

1965 Catalogue of Index Foraminifera, Vol. 1: Lepidocyclinids and Miogypsinids. American Museum of Natural History, New York.

Hally, David J.

1972 The Plaquemine and Mississippian Occupations of the Upper Tensas Basin, Louisiana. Unpublished Ph.D. dissertation, Department of Anthropology, Harvard University, Cambridge.

Hudson, Charles M.

1976 The Southeastern Indians. University of Tennessee Press, Knoxville.

Jeter, Marvin D.

2007 The Outer Limits of Plaquemine Culture: The View from the Northerly Borderlands. In Plaquemine Archaeology, edited by Mark A. Rees and Patrick C. Livingood, pp. 161-195. University of Alabama Press, Tuscaloosa.

Knight, Vernon J., Jr.

2006 Farewell to the Southeastern Ceremonial Complex. Southeastern Archaeology 25:1-5.

Knight, Vernon J., Jr., James A. Brown, and George E. Lankford

2001 On the Subject Matter of Southeastern Ceremonial Complex Art. Southeastern Archaeology 20:129-141.

Knight, Vernon J., Jr., and Vincas P. Steponaitis

2011 A Redefinition of the Hemphill Style in Mississippian Art. In Visualizing the Sacred: Cosmic Visions, Regionalism, and the Art of the Mississippian World, edited by George E. Lankford, F. Kent Reilly III, and James F. Garber, pp. 201-239. University of Texas Press, Austin.

Krebs, W. Philip, Polly Futato, Eugene M. Futato, and Vernon James Knight, Jr.

1986 Ten Thousand Years of Alabama Prehistory: A Pictorial Resume. Bulletin 8. Alabama State Museum of Natural History, Tuscaloosa.

Lankford, George E.

2007a The Great Serpent in Eastern North America. In Ancient Objects and Sacred Realms: Interpretations of Mississippian Iconography, edited by F. Kent Reilly III, and James F. Garber, pp. 107-135. University of Texas Press, Austin.

2007b The "Path of Souls": Some Death Imagery in the Southeastern Ceremonial Complex. In Ancient Objects and Sacred Realms: Interpretations of Mississippian Iconography, edited by F. Kent Reilly III, and James F. Garber, pp. 174-212. University of Texas Press, Austin.

Lawton, David E., F. J. Moye, J. B. Murray, B. J. O'Connor, H. M. Penley, G. S. Sandrock, W. E. Marsalis, M. S. Friddell, J. H. Hetrick, P. F. Huddlestun, R. E. Hunter, W. R. Mann, B. F. Martin, S. M. Pickering, F. J. Schneeberger, and J. D. Wilson

1976 Geologic Map of Georgia. State Maps 3. Georgia Geological Survey, Atlanta.

Lemley, Harry J., and Samuel D. Dickinson

1937 Archaeological Investigations on Bayou Macon in Arkansas. Bulletin of the Texas Archeological and Paleontological Society 9:11-47.

1964 Archaeological Investigations on Bayou Macon in Arkansas. Arkansas Archeologist 5(2):21-39.

L'Isle, Guilliaume de

1702 Carte de la Riviere de Mississipi sur les memoires de Mr. le Sueur qui en a pris avec la boussole tous les tours 
et detours depuis la mer jusqu'a la Riviere St. Pierre, et pris la hauteur du pole en plusieurs endroits. Manuscript map (original), Bibliothèque nationale de France, Département des cartes et plans, Ge SH 18 pf 138 bis div 3 p 2 . Fine copy, Library of Congress, Geography and Map Division, G4042.M5 1702 .L5 Vault. Electronic document, http://hdl.loc.gov/loc.gmd/g4042m.ct000665, accessed March 21, 2010.

Marigny de Mandeville, Antoine Phillipe de

1743 Carte particulière d'une partie de la Louisianne ou les fleuve et rivierres onts etés relevé a l'estime \& les routtes par terre relevé \& mesurées aux pas, par les Srs. Broutin, de Vergés, ingénieurs \& Saucier dessinateur/Demarigny. Manuscript map, Library of Congress, Geography and Map Division, G4010 1743 .D4 Vault. Electronic document, http://hdl.loc.gov/loc.gmd/g4010.ct000681, accessed March 21, 2010.

McDermott, John F.

1979 The French Impress on Place Names in the Mississippi Valley. Journal of the Illinois State Historical Society 72(3):225-234.

McGuire, Joseph D.

1899 Pipes and Smoking Customs of the American Aborigines, Based on Material in the U.S. National Museum. In The Report of the U.S. National Museum for 1897, pp. 351-645. Government Printing Office, Washington, D.C.

Moore, Clarence B.

1905 Certain Aboriginal Remains of the Black Warrior River. Journal of the Academy of Natural Sciences of Philadelphia 13:124-244.

1907 Moundville Revisited. Journal of the Academy of Natural Sciences of Philadelphia 13:336-405.

1909 Antiquities of the Ouachita Valley. Journal of the Academy of Natural Sciences of Philadelphia 14.

Moorehead, Warren K.

1910 The Stone Age in North America. 2 vols. Houghton Mifflin, Boston.

Neitzel, Robert S.

1965 Archeology of the Fatherland Site: The Grand Village of the Natchez. Anthropological Papers 51(1). American Museum of Natural History, New York.

Penney, David W.

1985 Continuities of Imagery and Symbolism in the Art of the Woodlands. In Ancient Art of the American Woodland Indians, edited by David S. Brose, James A. Brown, and David W. Penney, pp. 147-198. Abrams, New York.

Phillips, Philip

1970 Archaeological Survey in the Lower Yazoo Basin, Mississippi, 1949-1955. Papers 60. Peabody Museum of Archaeology and Ethnology, Harvard University, Cambridge.

Phillips, Philip, and James A. Brown

1978 Pre-Columbian Shell Engravings from the Craig Mound at Spiro, Oklahoma. Paperback ed., Pt. 1. Peabody Museum Press, Cambridge, Massachusetts.

Scarry, C. Margaret

1995 Excavations at the Northwest Riverbank at Moundville: Investigations of a Moundville I Residential Area. Report of Investigations 72. Office of Archaeological Services, University of Alabama Museums, Tuscaloosa.
Smith, Theresa S.

1995 The Island of the Anishnaabeg: Thunderers and Water Monsters in the Traditional Ojibwe Life-World. University of Idaho Press, Moscow.

Steponaitis, Vincas P.

1983 Ceramics, Chronology, and Community Patterns: An Archaeological Study at Moundville. Academic Press, New York.

Steponaitis, Vincas P., and Vernon J. Knight, Jr.

2004 Moundville Art in Social and Historical Context. In Hero, Hawk, and Open Hand: American Indian Art of the Ancient Midwest and South, edited by Richard F. Townsend and Robert V. Sharp, pp. 166-181. Art Institute of Chicago, Chicago.

Szabo, Michael W., W. Edward Osborne, Charles W. Copeland, Jr., and Thornton L. Neathery

1988 Geologic Map of Alabama. Special Map 220. Geological Survey of Alabama, Tuscaloosa.

Thruston, Gates P.

1890 The Antiquities of Tennessee and the Adjacent States. Robert Clarke, Cincinnati.

West, George A

1934 Tobacco, Pipes and Smoking Customs of the American Indians. 2 pts. Bulletin of the Public Museum of the City of Milwaukee 17. Milwaukee.

Williams, Stephen, and Jeffrey P. Brain

1983 Excavations at the Lake George Site, Yazoo County, Mississippi, 1958-1960. Papers 74. Peabody Museum of Archaeology and Ethnology, Harvard University, Cambridge.

\section{Note}

1. Given this setting, it is perhaps no coincidence that Glendon limestone was chosen so often to depict the Underwater Panther or Great Serpent, whom native peoples of the Eastern Woodlands associated with waterfalls, whirlpools, deep or turbulent water, and caves (Hudson 1976:130; Smith 1995). Indeed, not far south of where the Glendon limestone is exposed along the banks of the Mississippi today, near the mouth of the Big Black River, the early French colonists encountered a large whirlpool that they called Grand Gouffre, a name that survives today as Grand Gulf (McDermott 1979:233). This whirlpool must have been a major and persistent feature of the river, as it consistently appears on French maps throughout the first half of the eighteenth century (e.g., L'Isle 1702; Marigny de Mandeville 1743). There is no way to know, of course, whether it existed in Mississippian times or where other such eddies may have been located. That said, it is easy to imagine that any distinctive rock outcrop located at the water's edge near such a whirlpool would have been regarded as having spiritual power

Submitted August 13, 2009; Revised November 23, 2009; Accepted March 21, 2010. 